\title{
Complex Control and the Governmentality of Digital Platforms
}

\author{
Petter Törnberg* and Justus Uitermark \\ Department of Human Geography, Amsterdam Institute for Social Science Research, University of Amsterdam, Amsterdam, \\ Netherlands
}

Digital platforms are reshaping cities in the twenty-first century, providing not only new ways of seeing and navigating the world, but also new ways of organizing the economy, our cities and social lives. They bring great promises, claiming to facilitate a new "sharing" economy, outside of the exploitation of the market and the inefficiencies of the state. This paper reflects on this promise, and its associated notion of "self-organization," by situating digital platforms in a longer history of control, discipline and surveillance. Using Foucault, Deleuze, and Bauman, we scrutinize the theoretical and political notion of "self-organization" and unpack its idealistic connotations: To what extent does self-organization actually imply empowerment or freedom? Who is the "self" in "selforganization," and who is the user on urban digital platforms? Is self-organization necessarily an expression of the interests of the constituent participants? In this way, the paper broadens the analysis of neoliberal governmentalities to reveal the forms of power concealed under the narratives of "sharing" and "self-organization" of the platform era.

OPEN ACCESS

Edited by:

Andrew Karvonen

Royal Institute of Technology, Sweden

Reviewed by:

Alberto Vanolo,

University of Turin, Italy

Ugo Rossi,

University of Turin, Italy

*Correspondence:

Petter Törnberg

petter.tornberg@gmail.com

Specialty section:

This article was submitted to

Governance and Cities,

a section of the journal

Frontiers in Sustainable Cities

Received: 03 December 2019

Accepted: 25 February 2020

Published: 13 March 2020

Citation:

Törnberg P and Uitermark J (2020)

Complex Control and the

Governmentality of Digital Platforms.

Front. Sustain. Cities 2:6.

doi: $10.3389 /$ frsc. 2020.00006
We find that control is increasingly moving to lower-level strata, operating by setting the context and conditions for self-organization. Thus, the order of things emerge seemingly naturally from the rules of the game. This points to an emerging form of complex control, which has gone beyond the fast and flexible forms of digital control theorized by Deleuze.

Keywords: urban digital platforms, complexity, self-organization, governmentality, control

\section{INTRODUCTION}

Mark Zuckerberg recently gave a speech in which he pointed to the way that digital platforms like Facebook have "decentralized power by putting it directly into people's hands" (Zuckerberg, 2019). This is part of a broader discourse in which digital platforms make promises of freedom and free speech, often echoing the hopeful narratives of individual liberation of the 1960s counterculture movement. Free speech and individual freedom, as both Zuckerberg and counterculture activists argued, will empower the powerless and push for improvements in society.

The updated version of these narratives, however, have a new digital bend to them: people will be empowered to organize through the decentralized meeting-places created by digital platforms. As Jim Whitehurst, CEO of the open source company Red Hat, puts it, "Uber has shown how you can actually empower many thousands of people to self-organize" (Whitehurst, 2016). Digital platforms have brought about the idea that society would not need leaders but organize itself as "bottom-up cooperation coalesces into an ingenious and complex social organization" (Uitermark, 2015). This vision looks particularly attractive in an era in which both the market and the state are increasingly losing their appeal due to rising inequalities and authoritarianism. Platforms suggest replacing the top-down control of the state and institutions, with the harmonious, spontaneous, and non-political self-organization of individuals (Benkler, 2006; Helbing, 2015). 
This narrative is based on fundamental dichotomy between on one side the static, linear and top-down, and the other side the open, informal, and non-linear-where the former is seen as the domain of control and domination, and the latter of freedom and informality (Krivý, 2018). This dichotomy is echoed throughout the literature on digital technology (Sennett, 2012) and the amorphous concept of "smart cities" (Rossi, 2016; Zandbergen and Uitermark, 2019). This dichotomy can be traced back to the now classic opposition between the bottom-up "organized complexity" of Jacobs (1961, p. 429), and the top-down planning of her arch-nemesis Robert Moses. Digital platforms promise to deliver Jacob's spontaneous self-organization into the modern era. While they are changing society writ large, their impact has been in particular fundamental to the urban experience, and the vision of self-organization has come to stand in for a broader shift in thinking within urban governance (Gershenson et al., 2016).

This paper reflects on this vision, and in particular its associated notion of "self-organization," by situating digital platforms in a longer history of control, discipline and surveillance. Using Foucault, Deleuze and Bauman, we scrutinize the theoretical and political notion of "self-organization" and unpack its idealistic connotations: To what extent does selforganization actually imply empowerment or freedom? Who is the "self" in "self-organization," and who is the user on urban platforms? Is self-organization necessarily an expression of the interests of the constituent participants? In this way, the paper broadens the analysis of neoliberal governmentalities to reveal the forms of power concealed under the narratives of sharing and self-organizing of the platform era.

\section{DIGITAL PLATFORMS AND DREAMS OF SELF-ORGANIZATION}

Digital platforms have in recent years grown into powerful institutions for the exchange of information, goods, and services. These platforms have become so important that they take on the form of indispensable infrastructures for social and economic life (Plantin et al., 2018). Digital technologies are launched under one of a plethora of marketing pre-modifiers: "smart," "social," or "sharing"- signaling the idea that they provide "spaces" for social interaction. User-generated content has to such degree become a standard aspect of new technologies that "digital" and "social" are increasingly used as synonymous (Marres, 2017).

A central part of the marketing of these platforms is an emphasis on progressive values, calling upon ideals of the counterculture movement: the digital platforms present themselves as providing spaces for personal liberation where everyone can speak their mind, fulfill their intellectual and democratic potential, and express their individuality (Zuckerberg, 2019). They promise to leave behind the passivity of traditional mass media and invite citizens to participate, think for themselves, and express their own views.

This links to a broader idea, seen in concepts like the "sharing economy" (Puschmann and Alt, 2016) or "commons-based peer production" (Benkler, 2002): that these platforms are providing an alternative to both the market and the government. Digital platforms are bringing a deep optimism about the advent of a new, less hierarchical society:

While one might think that a largely self-regulating society is utopia, a new kind of economy is already on its way. Social media are networking people and, thereby, enable "collective intelligence." ... Social media platforms, such as Amazon Mechanical Turk make it possible to bring ideas and skilled workers together. As a consequence, this leads to a more direct participation of people in production processes (Helbing, 2015, p. 3).

Central to these ideas is the increasingly prominent notion of self-organization. Self-organization has in recent years become an important idea-both as a political ideal and as a theoretical concept (Sørensen and Triantafillou, 2009; Arnouts et al., 2012).

As a political ideal, the term self-organization is used to describe a wide variety of governance arrangements where private actors take their own initiative to autonomously act and pursue public or collective objectives (Mattijssen et al., 2018). The concept has provided the theoretical foundation on which digital platforms have made claims to provide a third option in the previous choice between state and the market-which in an era of growing inequalities and authoritarianism has increasingly become seen as a choice between Scylla and Charybdis. New digital technology, which is seen as affording new forms of social organization, disintermediated and without central leadership (Uitermark, 2015). Platform technology has thus breathed new life in the visions of societies organized without delegating power to a central authority. Wikipedia is perhaps the ultimate example. The encyclopedia was initially conceived as a project relying on the authority of experts and revenues from advertisements, but Wikipedia only took off after it became a non-profit and invited everyone to edit and add. Hundreds of thousands of volunteers have contributed to Wikipedia on their own initiative and without central coordination, collectively creating a giant and evolving repository of human knowledge. The idea that people will spontaneously and harmoniously self-organize if given the opportunity also animates enthusiasm for digital platforms of the "sharing economy," like Airbnb, Uber, CrowdFunding, HomeAway, or social media platforms like Twitter, Reddit, or Facebook (Benkler, 2006; Srnicek, 2017).

This narrative has begun to spill over into how these companies pursue their policy interests and mobilize their user base. Airbnb, for instance, is employing the narrative of selforganization to describe their "Airbnb Citizen initiative," in which the company cultivates so-called Home Sharing Clubs: groups "whose host members share best practices, partner with local organizations on volunteer work, engage with neighborhood businesses, and advocate to local policymakers for fair, clear rules" (Airbnb, 2016). This, in practice, implies that they put pressure on policy-makers and push for "home owners' rights," that is, the "right" to short-terms rental of housing property. Airbnb forms and manages these communities, and they thus exist somewhere on the spectrum between corporate outsourcing of lobbying operations and the facilitation of interest-based advocacy (van Doorn, 2019). Airbnb, however, 
simply describes these communities as "self-organized" (e.g., Airbnb, 2019, p. 33).

As a theoretical concept, self-organization was brought into contemporary use by Cybernetics scholars, in particular by Wiener (1948) and Ashby (1991). The concept, as well as the Cybernetics movement at large, was over time subsumed by Complexity Science (Johnson, 2009; Mitchell, 2009), which has grown into a paradigmatic epistemology within both the natural and social sciences in recent years-not least as foundation of the emerging discipline of Computational Social Science (Törnberg and Törnberg, 2018). Within Complexity Science, self-organized systems are often defined as systems in which the components "are to some degree independent, and thus autonomous in their behavior, while undergoing various direct and indirect interactions" (Heylighen et al., 2006, p. 125). The concept draws on the study of the collective behavior of social insects, like ants or bees, which have been found to organize without centralized leadership or control: each bee or ant simply follows its own simple instincts (Bonabeau, 1998). Despite of this, they are capable of carrying out sophisticated feats of organization. For instance, ants build bridges to cross chasms, construct antiflooding systems in anticipation of storms, farm, make gardens, and organize wars. They even maintain advanced climate control, and run massive public work projects on a scale that makes the New Deal pale in comparison. And they do all this without planning, leaders, or architects. The intelligent organization of the colony emerges from local mass-interactions of the individual ants (Mitchell, 2009; Ball, 2012).

Within Complexity Science, self-organization is thus one of the defining feature that distinguishes "complex systems" from "complicated systems" (Andersson and Törnberg, 2018). While complicated systems are assembled, complex systems selforganize (Bar-Yam, 1997). This distinction between complex and complicated systems is central to the conception of selforganization, and worth dwelling on. Complicated systems are like sophisticated machineries; top-down, hierarchical and bureaucratic, each of their components designed to carry out an organized function that fits into a larger structure. Such systems can be made highly efficient and capable of executing largescale tasks with extreme precision, but they are at the same time brittle: fragile to internal and external disturbances, and lacking in their capacity to adapt to shifting circumstances (Michod and Nedelcu, 2003). Complex systems, on the other hand, tend to have less functionally differentiated components, and are instead organized through a large sets of interacting components on same organizational level (Andersson and Törnberg, 2018). Complex systems tend to be more flexible and adaptive than their complicated counterparts, since modifying functionality does not require a redesign of the entire system, but can often be carried out through self-organization. While complicated systems are fragile and sensitive to disruptions, complex systems are thus resilient due to their inherent redundancy: components may step in for other components. Simply put, the effects of disruption in complex systems is more like removing an ant from an anthill than removing a cog from a sophisticated machinery.

This conception of complex systems has become the epistemic foundation for a broader shift within urban governance, from "complicated" to "complex," illustrated by notions, such as "network governance" (Jones et al., 1997) and "adaptive governance" (Folke, 2007). These constitute discourses describing a move from bureaucratic structures within firms and formal relationships between them, to organic or informal social relations. This shift is often motivated by the requirements on adaptability and resilience imposed by the rapid changes resulting from current crises of large-scale social-ecological systems (Gunderson and Light, 2006), but has also been linked to a broader shift toward neoliberal modes of urban governance (Joseph, 2013; Chandler, 2014; Blanco, 2015). The discourse of digital platforms as enabling self-organization can thus be seen as part of a broader shift toward complex and decentralized governance.

This is thus the context and the theoretical roots from which digital platforms are weaving new visions of an anarchic future. Uitermark (2015) describes this as a "longing for Wikitopia": the ideal of a self-organized city, where people are not directed by central authorities but cooperate voluntarily in communities and for the public good. Just like ants, this society rises from the bottom-up interaction of individuals, coalescing into a highly functional social organization. This vision has empowered a range of initiatives, from urban gardening (Mattijssen et al., 2018) via technology hubs (Moisio and Rossi, 2019) to childcare facilities and makerspaces (Chiappini and Törnberg, 2018). Digital platforms are seen as hubs for coordinating and meeting, disintermediated and leaderless, to solve collective problems. As Helbing (2015) puts it:

Digital revolution is thus seen as allowing distributed (self-)control, i.e., bottom-up management. In fact, cybernetics (i.e., control theory) and complexity theory tell us that it is feasible to create resilient social and economic order by means of self-organization, self-regulation, and self-governance (Helbing, 2015, p. 2).

While this governmentality is covered in an antipolitical veneer, it reflects and reinforces a particular value-system: "while the logic through which uncoordinated and individual decisions produce social outcomes is readily accepted as a consequence of intrinsic principles of self-organization that have to be respected, the logic through which collective and coordinated decisions produce social outcomes is suspect" (Uitermark, 2015, p. 2303). In other words, the "top-down" organization of governments and institutions is seen as an unnatural expression of constraint and control, while the "bottom-up" of decentralized systems is an expression of the natural and free will of the participants. What are the antecedents of this type of governmentality?

\section{THE GOVERNMENTALITIES OF DIGITAL PLATFORMS}

A virtually inevitable starting-point for tracing the genealogy of contemporary governmentality is Foucault (1977) Discipline and Punish, the main thesis of which is that the first half of the nineteenth century saw the replacement of punishment as a public spectacle by forms of incarceration that worked through 
techniques of discipline and correction. "At the beginning of the nineteenth century... the great spectacle of physical punishment disappeared; the tortured body was avoided; the theatrical representation of pain was excluded from punishment. The age of sobriety in punishment had begun" (1977, p. 14). In Foucault, the disciplinary society was founded on the omnipresence of surveillance, the arch model of which was the Panopticon: a prison and system of control designed by Jeremy Bentham in the eighteenth century, with an architecture organized in such a way that all prisoners of an institution can be observed by a single security guard, without the inmates being able to tell whether they are being watched. The power of the Panopticon thus rests on the limitless capacity for watching, or what Bentham calls the "apparent omnipresence of the inspector" [Bentham's (1995), p. 45].

This form of power was a quintessential part of modernity is perhaps most visible in its dystopias and nightmares (Bauman, 2013): Orwell and Huxley's worlds might have differed in almost every detail, but they shared a common foreboding of a tightly controlled world, repressing any expression of individual freedom. This was the natural extrapolation of the control of high modernity (Arendt, 1973; Bauman, 2013). Critical theory was thus aimed at fighting the machinery, with its homogenizing and implicit totalitarian tendencies, while defending individuality, freedom and the right to be different (Horkheimer, 1972). The aim was to liberate individuality from the totalitarian homogeneity, tearing down the machinery of modernity to release workers from their factory cages as free individuals.

But as the disciplinary society faded, the result was-to scholars like Michel Foucault, Gilles Deleuze, and Zygmunt Bauman-not liberation and freedom, but rather new forms of discipline and control. These forms of control, we argue, have since continued their evolution into their current embodiment in digital platforms.

\section{Subjectivities of Neoliberalism and Digital Platforms}

Digital platforms are promising individual liberation and freedom, in the form of a bottom-up alternative to both the market and the state, in which individuals are to self-organize without central leadership. But this begs the question: who is the new individual of the platform? What are the subjectivities of the "user"? Airbnb refers to their users as "citizens"-but who is the Airbnb citizen? What type of freedom are afforded by the arena in which these "citizens" meet?

In his analysis of the post-disciplinary society, Bauman (2013) focused on the ostensible dissolution on the top-down and Panoptical forms of power characteristic of disciplinary societies. For Bauman (2013), the transition was characterized by the dissolution of institutional structures, carrying an unfulfilled promise of new individual freedoms. For Bauman, the freedoms handed down to individuals through this transition were the freedoms of a consumer society, which meant that they were accompanied by political disempowerment: the space for mobilizing and acting as political beings were closed down, thus transforming citizens into mere consumers, without capacities for political action.

For Bauman, freedom necessarily has a collective basis, and the individualization of the post-disciplinary society thus implies a new form of disempowerment. Bauman argues that individualization and the absence of top-down control are not equivalent with freedom or even of empowerment of individuals: just because something is individualized and "bottom-up" its outcomes are not necessarily in the interest of its constituents or an expression of their will. Market choice is not a substitute for political action, and neoliberalization and its associated shift to individualized forms of politics and power were thus not a shift toward increasing freedoms.

While neoliberalization brought the construction of certain neoliberal subjectivities-which for Bauman implied that its promised freedoms were merely the illusory freedoms of consumerist individualization-its capacity for shaping subjectivities were in certain ways relatively coarse. In comparison, digital technology allows unprecedented flexibility in constructing the subjectivities of its users. The digital interface constitute an encoding of an epistemology, representing what is important and how the user can navigate the world, by what it include and what it leaves out (Halpern, 2015; Kitchin et al., 2017). Those representational logics structure the agency and subjectivity of user, not merely by defining the user role, but by constructing her as a subject and define, in part, how she conceives of, relates to, and inhabits her social world. The digital platform interface thus embodies a kind of ontology: it defines what the world is and is not. How a user will act is a function of what affordances and view of the world that the platform provides and the details of how these are implemented. While the use is free in the sense that she gets to choose from a menu of options, what is on the menu, the order of the options, or the subtle designs that shape how it is perceived, is provided by the platform. Precise algorithmic design allows great flexibility to promote certain forms of subjectivities (Isin and Ruppert, 2015).

An example of the way choice is constructed on platforms can be found on Netflix. The Netflix recommendation system is often hailed as an algorithmic success story, argued to be capable of knowing us "better even than we know ourselves" (Gomez-Uribe and Hunt, 2016):

\footnotetext{
Ask users what movies they plan to watch in a few days, and they will fill the queue with aspirational, highbrow films, such as black-and-white World War II documentaries or serious foreign films. A few days later, however, they will want to watch the same movies the usually want to watch: lowbrow comedies or romance films. People were consistently lying to themselves (StephensDavidowitz and Pinker, 2017).
}

This system "in total influences choice for about $80 \%$ of hours streamed at Netflix" (Hallinan and Striphas, 2016). Just like other comparable recommendation systems, its inner workings are "wired shut" with patent and trade secret laws, non-disclosure agreements, non-compete clauses, and other legal instruments 
(Bottando, 2012; Vaidhyanathan, 2012; Hallinan and Striphas, 2016).

Such recommendation systems are both ubiquitous and central to digital platforms. Their impact is particularly visible in the city, where the recommendations of platforms like Google Maps, Airbnb, and ClassPass are powerfully reshaping flows of people-and thereby the social web of the cities. The platforms are directing their users to specific places in the city, sorting geographies through software (Graham, 2005).

This recommendation system has come to intervene in our daily life, claiming to help us make "better decisions" (Hallinan and Striphas, 2016). However, the difference between what we claim to want and how we then act, is not a matter of "not knowing our true selves," but an expression of an inner struggle between who we want to be and our drive to satisfy our immediate urges. These are both expressions of a true self, but from two separate systems of evaluation-the Id and Superego, if you will. Netflix and similar recommendation technologies are in this sense intervening in an internal struggle, taking the side of immediate urges and whims, pushing for the immediate satisfaction of any wishful impulse-regardless of our higher ambitions. When our worst instincts are pitted against the better angels of our nature, the algorithms are thus standing firmly on the side of the instincts. The self is not fixed or definite, but rather a relational, malleable and porous entity (Conradson, 2016; Kingsbury and Pile, 2016), and digital platforms make use of precisely this malleability to shape their users into their most profitable selves. This is not merely an algorithmic solution to a claimed problem, but an intervention in the conceptual foundations of culture, implementing a profitable answer to a difficult question of who we are.

Similarly, social media and computer games are aimed to, as they say, optimize engagement or what would be called addiction if it were about drug use. They implement in their technology whatever instrument or insight for social control they have come across, whether discovered in casinos or in social psychology textbooks. This weaponized social psychology is ripe with unexpected social and psychological externalities. For instance, it is widely documented that negativity engages (Rozin and Royzman, 2001), and this is identified by algorithms and used as a way to drive engagement. This turns our public sphere turn into an addictive outrage machine, affecting the political and social climate with hard-to-predict outcomes (Lanier, 2017). While the subject of neoliberal society is the consumer, thus limiting political freedom, the platform subject is a significantly more controlled and reduced subject, whose agency is manufactured in such a way as to best fit the profit motives of platforms. Through platform design, the platform citizens' agency can be reconfigured as easily as the platform can itself, making the "conducting of the conduct" of subjects precise and efficient (Vanolo, 2019).

\section{Panopticon, Synopticon, and the Social Synopticon}

Central to understanding governmentalities of societies is to consider the way they structure surveillance and control (Gane,
2012). Foucault (1977) encapsulated the structure of control in disciplinary societies through Bentham (1995) metaphor of the Panopticon: a guard watching over the prisoners from a central watch tower. But the self-organization of digital platforms is promising a decentralized, leaderless society without central guard towers-does this imply a society without surveillance and discipline? If not, how do we understand the dominant mode of surveillance and enforcement of discipline of platforms?

Bauman (2013) characterization of the individualization brought with the fading of disciplinary societies again provides a starting point for tracing the antecedents of the platform govermentalities. Bauman's theory of individualization came with an analysis of the new forms of surveillance and discipline for which the metaphor of the Panopticon were no longer sufficient. He wrote of a Synopticon: mass media, and television in particular, had brought a society in which the many watch and admire the few. The Synopticon produced human beings who control themselves through self-control to fit neatly into capitalist society, by modeling themselves to the televised ideals. With this, the spectacle again takes the place of surveillance, but without losing disciplining power; obedience not by coercion, but through enticement and seduction. Control thus takes the form of the exercise of free will; we admire and follow the examples we see without someone telling us we must do so.

The Panopticon was founded on the notion of a single guard watching over the many prisoners, and the Synopticon is the mode in which the many can watch and admire the few. Within contemporary society, however, a new model is growing in significance: the social Synopticon of digital platforms, in which the many watch the many. This is in part enabled by the way that social media provide ways to interact and give feedback through comments and likes, in practice providing tools that afford the policing of identity expressions. Sundén (2002) describes this as a mirror, through which we view ourselves in the eyes of others, using this image to "write ourselves into being," relating our story about who we are to the social structures we see around us. This social Synopticon is carried out in ways that are tightly bound up with the design of the platforms, and in particular various forms of social indicators of reputation and standing (Ert et al., 2016).

Snapchat, one of the currently most popular apps among young users, is an excellent source of such examples. The platform has implemented multiple measures inspired by social psychological research, for instance the so called Snapstreak. Snapstreak is a measure of the number of consecutive days that you and a friend have sent direct snaps messages back and forth. Streaks are thus tangible, almost physical, proofs of friendship, as well as important status markers as they ostensibly provide a measure of popularity. Many teens invest significant time and effort in creating long streaks, which are awarded with fire or mountain icons, and losing a streak can be a devastating blowan expression of disinterest. For the Snapchat engineers, the aim of this is, of course, to push users to return daily and spend more time on the app thus being more exposed to advertising. It is hard to predict the long-term social consequences of such a largescale psychological experiment in which human insecurities and desires are gamified for corporate profits. 


\section{Foucault and Self-Organization as the New Laissez-Faire}

Foucault's (2008) lectures on biopolitics include an analysis of the notion of laissez-faire, which prove useful for deconstructing also the notion of self-organization. Foucault traced the conceived opposition between the "bottom-up" of the market and the "top-down" of the state to a transition in the late eighteenth century when scholars of the state and social order contemplated the idea of a creating a self-regulating market. With this shift, the market started to appear as something that "obeyed and had to obey "natural," that is to say, spontaneous mechanisms" (Foucault, 2008, p. 31). This brought a new relationship between the state and market, empowering the market while putting limits on the powers of the state. This is the roots of the notion of "laissez-faire" implying that a free market is the natural state, while government power is seen as unnatural. Foucault saw in this notion a "naive naturalism": as Polanyi (1944) famously argued, the market did not emerge spontaneously; it had to be constructed. Competition and market freedom thus did not come about naturally, and, as Foucault argues, continuously have to be monitored and subjected to governmental "control, constraint, and coercion" (2008, p. 6). This means that, ostensibly paradoxically, "economic freedom ... and disciplinary techniques are completely bound up with each other" (2008, p. 67). Competition and its "game, mechanisms, and effects [are] not at all natural phenomena" (Foucault, 2008, p. 120).

This means that the role of government in neoliberalism "should not be identified with laissez-faire, but rather with permanent vigilance, activity, and intervention" (2008, p. 132). Neoliberalization means not that the state steps back but rather that its techniques of control take on market forms. Audits, indicators and rankings are for Foucault examples of the way the state can promote competition and thereby compel self-discipline and self-surveillance. This form of control is based on tuning and shifting the market competition, using flexible and marketbased forms of control, while concealing and de-politicizing through technical coding, which modifies the competition within the market, rather than regulating top-down. An example of this are the international indexes and rankings provided by institutions like the World Bank, and used by companies around the world to decide with which markets to engage. Such indexes are described as objective and level playing fields, within which nations and institution can compete for global capital, in line with the neoliberal and individualist ideal of free entrepreneurial competition (Harvey, 1989). However, the indexes are also ways to promote a market agenda, making the reality of the indexes far from as objective and technical as is claimed. This can be seen in a recent instance involving the World Bank's Ease of Doing Business index. Over the last 10 years, Chile has plummeted in the index, going from 25 th to 55th place in the ranking-despite the fact that no major policy change had taken place. What had, however, taken place in Chile was the election of a socialist president, Michelle Bachelet. Closer inspection revealed that subtle tweaking in the definition of the index was causing Chile to alternate between climbing and falling in the ranking, as the nation alternated between Bachelet and conservative Sebastián Piñera. This shows how rankings provide ways to technically encode political perspectives, in order to promote certain policies and agendas (Zumbrun and Talley, 2018).

The idea that self-organizing systems are spontaneous, while top-down control is artificial, is essentially a return of the notion of "laissez-faire" in new clothing. Just like the market was seen as something that "obeyed and had to obey "natural," that is to say, spontaneous mechanisms" (Foucault, 2008, p. 31), so does this broader category of leaderless complex systems. Foucault's deconstruction of laissez-faire applies equally well here: selforganization, just like markets, "should not be identified with laissez-faire, but rather with permanent vigilance, activity, and intervention" (2008, p. 132). In the case of platforms, this vigilance is carried out not by governments, but by the platform companies-who in turn partially outsource it to the users themselves. Digital platforms are far from disintermediated: they are constituted by a tangle of rules and procedures for sorting information, nudging and surveilling, with the ultimate goal of benefiting their owners (Weinmann et al., 2016; Marres, 2017). The user is always audited, and manipulated in behavioral experiments with the aim of learning how to best steer and nudge the users in profitable directions. Even Wikipedia, the basis of the dreams of "Wikitopia," on closer examination has a significant amount of top-down efforts in the forms of management, surveillance and intervention (Uitermark, 2015). The Wikimedia Foundation that supports Wikipedia, has over the years come to play a bigger role, often pushing or crowding out initiatives by collectives of volunteers (Rijshouwer, 2019).

Central to "self-organization" and "complexity" as theoretical concepts is an inherent notion of spontaneity. The emergent patterns observed in these systems tend to be seen as natural, or even inevitable. That phenomena that spring from massinteractive systems are hard to link to specific causal roots is taken as a sign that they are "spontaneous"-as if micro-level causes were not just as much a function of external constraints and conditions. But just like markets, platform self-organization has to be constructed. The notions that digital platforms are "social" and that they enable "disintermediated" forms of interaction are embodying the same naïve naturalism as Foucault identified in the notion of "laissez-faire." While platforms are marketed under the notion of "making technology social," their actual impact tends rather to be to make the social technically mediated by transforming modes of interaction into quantified and datafied forms that permit control through intervention and manipulation (Van Dijck and Poell, 2013). Social technology thus constitutes a centralization of the modalities of social interaction, giving private institutions the power to nudge and shape our very modes of communication. Social media are tools and methods for the social world, employing quantification that distorts the social reality and carries ideological choices in their technical codification (Feenberg, 2002).

One way of understanding this is through the literature on behavioral economics, where idea of "nudging" was developed (Thaler et al., 2013). Through this lens, digital platforms embody "choice architectures" which drive the user's behavior by shaping the contexts in which they make decisions. While choice architectures are inescapable-our decision-making always takes place in a given context and with limited information-nudging 
is the rigorous process of designing the architectures to alter behavior in predictable ways. This shaping may take place through modifying what information is presented, what the options are, what the default choices are, or by creating different forms of implicit or explicit awards, scores or ratings. Ratings and scorings are particularly salient examples that are frequently used to "gamify" and nudge users toward certain behavior (Vanolo, 2019).

Examples of the way ratings and scoring shape social life can be seen in the way "quantified self" (Lupton, 2016) systems like FitBit are nudging us to measure our productivity, health, and well-being, with the implicit imperative to self-regulate and optimize in relation to e.g., health care, education, and workplace productivity (Vanolo, 2019). A less subtle example is the way ratings are encoded and employed to create decentralized forms of "self-governance" that is found in the various Chinese social credit systems that assign scores to citizens based on their behavior (Liang et al., 2018). These constitute expansions of traditional credit score systems to take into account additional data to rate an individual, and thereby shape his or her behavior in line with the interests of the Chinese state. There are several such systems currently in operation, generally using data on consumption behavior, wealth, social connection, etc., to calculate a score. There are furthermore currently attempts being made at unifying a number of different social credit scores into a single "social trust," which will provide a publicly available rating of citizens. The social ratings have a range of consequences, from the success of one's visa applications to being displayed on online dating platforms. This makes it a powerful tool for shaping individual behavior, while remaining a seemingly decentralized form of self-governance, as it becomes part of individuals' everyday social lives (Vanolo, 2019).

This notion of self-organization as natural often takes the form of stripping problematic outcomes from their conflictual and power-struggle dimensions. For instance, digitization is widely observed to have brought the ubiquity of highly asymmetric "long-tailed" distributions, in which a few actors receive a majority of the resources of the digital platforms-whether income, attention, or influence. While spatial structures tends to bring normal distributions (Feynman, 1964), the networked architecture of digital media tends to bring about extremely uneven distributions (Castellani and Rajaram, 2016). This could - and arguably should - be cast as the outcome of a political design choice, but it tends to instead be seen as an inherent aspect of digital technology. Researchers describe it as following from foundational micro-properties of networked systems, such as "preferential attachment," i.e., the increased likelihood for nodes to connect to more well-connected hubs (Barabási and Albert, 1999). The fact that the platform design creates the micro dynamics of preferential attachment, which then in turn produce the problematic macro level outcomes, is disregarded. As Krivý (2018) puts it, this is the politics of the "end of politics." Thereby, the unequal outcomes of self-organizing systems are stripped of their political, conflictual and power dimensions, and cast as inevitable and natural.

\section{Complex Control}

Together, these points illustrate the way digital platforms emphasize forms of control that constitute a departure from previous forms of governmentality. To draw the genealogy of the new dominant mode of control that is traced by these points, we turn to Deleuze's (1992) conceptualization of the transition of power that was part of the transformation from disciplinary to post-disciplinary societies.

In Deleuze's view, as the disciplinary society faded by the middle of the 20th, new flexible and mobile techniques of power, "ultrarapid forms of apparently free-floating control" (Deleuze, 1992, p. 178), rose in their place. Deleuze argued that control replaced discipline, and referred to these new societies as "control societies," distinguished from disciplinary societies, with the latter working through fixity and confinement and the former through mobility and speed. While discipline, as high modernity more broadly, was based on fixed form and heavy architectural structure, control is constantly modulatedit can be open or closed, enabling movement for some while immobilizing others. This was founded on new, more flexible technologies. While the disciplinary societies were founded on technologies of incarceration and total institutions, the control societies were founded on "a third generation of machines, with information technology and computers" (Deleuze, 1992, p. 180). Digital systems thus enable the same evolution as can be seen in contemporary capitalism at large, combining flexibility and speed of control, making it "short-term and rapidly shifting, but at the same time continuous and unbounded, whereas discipline was long-term, infinite, and discontinuous" (Deleuze, 1992, p. 181). While Deleuze overstated epochal shifts-he wrote at the dawn of the era of mass incarceration and underestimated the extent to which brute force would continue to buttress power (Wacquant, 2010; Sassen, 2014) he was prescient in other respects in elaborating how the early forms of computer and information systems that existed at the time of his writing remolded power in the same ways as they did capitalist production: from heavy and structured, with the fixed boundaries and confinement, to flexible, dispersed and fluid.

But the control seen in digital platforms, the outlines of which we can already glimpse in the analyses above, seems to have moved beyond even what Deleuze described. With progress of digital technology since Deleuze's (1992) writings, the technological shaping and nudging of behavior can now be exercised in more sophisticated, nimble and elusive ways than ever before. Digital platforms can constantly shift underneath our feet. It is not only the pace of change of new technology that has changed with digitalization, but also feedbacks of evaluation of how new innovations affect the social web in which they become part. Complexity Science approaches, in the form of sophisticated data analysis, A/B testing, and instantaneous evaluation of the social practices evolving on digital platforms enable platform companies to shape their users' behavior with unprecedented precision and control. The feedback loop between evaluation and changing of technology (Lane, 2016) has become increasingly rapid, as technology owners have 
precise and detailed data on how their products become part of a larger sociotechnical context. This has brought perhaps the most important shift in the expression of power from the control society identified by Deleuze: we are seeing the rise of a new cybernetics, as control has become scientific in its application.

Control in the era of digital platforms is expressed not through top-down command, but through invisible nudging and shaping of local behavior: it is embedded in the very rules of interaction; what we may refer to as complex control. Like in a complex system, the desired outcomes emerge from micro-interactions, but the difference is that system designers-iteratively, experimentally, incrementally-develop and harness features to the extent that they further the interests of the platform's owner. As digitization is permitting the rapid formation of mediated platforms, control increasingly moves to lower-level strata. This is the power of designed selforganization. It constitutes a transition from Deleuze's control, to letting the outcomes emerge seemingly naturally from the order of things; power is now expressed as the subtle tuning of some technical code of a performance indicator, which brings about a cascade of change among in networks of interacting players.

While the flexibility and fluidity with which this is carried out is new, it is not an altogether new form of control. These transformations are reminiscent of Elias (1969) analysis of the power transformation of the court of Luis XIV. Elias observes a transformation of power from the exercise of brute force to a more subtle and diplomatic game. Luis used the ceremonies of Versailles to construct a network of social status that upheld social control. Instead of requiring well-organized central control of the nobility, the control was distributed, put into the fabric of interaction, through a status hierarchy organized around the center of power. Through this, Luis' interests were upheld not through direct command-and-control, but as an outcome of the very rules of the game-and the nobles had little choice but to play this game. Today, the rules of such games are constructed by highly flexible digital technology, making the games liquid and capable of expressing precise control.

Just like the market has been surrounded by notions of natural, and inevitable, so are the ideas of self-organization today. This often comes together with a normative dimension, in which emergence and self-organization is seen as inherently positive. While emergence in natural systems is natural, in the sense that the underlying physical laws are timeless and universal, the rules of our social games are notthey are constructed and negotiated, and therefore local and temporal. There is in this sense nothing natural about selforganization. Part of this naturalization is a tendency toward seeing emergent phenomena as inevitable, since the outcome is not the active intention of any of the actors involved, but rather the outcome of something intangible between the actors. Neither is there anything inherently good about selforganization: that a phenomenon emerges bottom-up does not mean that it embodies the will of its constituents or serves their interests.

\section{CONCLUSIONS}

This paper has revisited work on discipline and control, to thereby trace the genealogy of, and critically examine, the governmentalities of the contemporary platform era, identifying and adapting a number of key concepts to capture the forms of control inherent to digital platforms.

\section{Platform Subjectivities}

Bauman critiqued the notion of freedom in the individualized society through an examination of the constructed subjectivities of the neoliberal individual. Digital platforms, similarly, are powerful technologies for shaping the subjectivities of their users, providing certain affordances and interfaces that embody epistemologies shaping what a user is, putting limits on how she conceives of, relates to, and inhabits the world. While Airbnb refers to their users as "citizens," they could not be further from the political animals of the polis or agora, their capacity for action being limited to what the platform permits (Arendt, 1958).

\section{Surveillance}

Bentham's/Foucault's Panopticism of the discipline society, in which the few watched the many, and Mathiesen's/Bauman's Synopticon of the mass media era, in which the many watched and admired the few, have now been replaced by a social Synopticon-in which the many watch the many. Social media platforms have replaced mass media as the locus of conformity and self-discipline, as they have grown into important arenas for the formation and enactment of social identities.

\section{Laissez-Faire Self-Organization}

Foucault deconstructed the notion of "laissez-faire," critiquing the notion that a free market is somehow the natural state, on which government power is merely infringing. But the same idea has resurfaced as part of the notion of "self-organization," as it contains a value-system in which the outcomes of uncoordinated and individual decisions are spontaneous and have to be respected, while collective and coordinated decisions are controlling and limiting, and thus suspect (Uitermark, 2015). But just like the market, self-organized systems are constructed, and need to be constantly maintained through "control, constraint, and coercion" (Foucault, 2008, p. 6). These narratives of self-organization thus serve merely to naturalize and hide the forms of control that underlie platforms; there is nothing natural about self-organization.

These dimensions intertwine to together constitute the governmentality of digital platforms: what we refer to as complex control. Deleuze wrote of the shift from the slow and fixed power to fast, flexible and shifting forms of control, enabled by early computer technology. With platforms, control has gone through another qualitative shift, increasingly moving to lowerlevel strata: by setting the context and conditions for selforganization, the order of things emerges seemingly organically from self-organization. But self-organization itself is organized. Designers tweak continuously to achieve those types of selforganization that are compatible with the financial interests of the platform's owners. This is the control of digital platforms: 
the platform city is the urban embodiment of Deleuze's (1992) society of control. Its new instrument of control is horizontal, decentralized, networked communication.

There is an ostensible paradox at the core of this: the very notions of bottom-up, contingency, complexity and unpredictability have become instruments of control within the governance models informed by complexity science (Krivý, 2018). The association between top-down command-and-control and oppression runs so deep that describing this new form of control requires an almost Orwellian language ("freedom is slavery," as the newspeak slogan went). But that centralization was the dominant mode of discipline and control during the twentieth century should not blind us to the novel forms of power relations and control enacted through decentralization and self-organization. While the modern society was founded on linearity, stable states, and negative feedback, the complex control of the platform era embraces chaos, positive feedbacks, and non-linearity.

While digital platforms may seem to create individual freedom, they in part do so by concealing the pushing, nudging and pulling that set the context and boundaries for that individual freedom, and that are at the core of what digital platforms are. Digital platforms are bundles of rules whose function is to direct interaction to become "organized" by enabling certain forms of action while preventing other. Digital platforms do not bring disintermediation; au contraire, they add additional mediation by expanding technological control into new parts of social life. They provide the "choice architecture" within which we act, and provide the configurations that determine what is possible-indeed what is thinkable-and what is not.

This changed understanding of what digital platforms are has implications not only for how we should view the political claims of platforms, but also how we study them and the data they produce. What type of epistemologies are required for a critical examination of self-organization as a form of control? How do we critically study platforms through digital data?

So far, the pre-modifier "computational" seems to preclude "critical." Computational Social Science is in large part founded upon Complexity Science, resulting in a naïve naturalist epistemology that assumes social processes can be studied

\section{REFERENCES}

Airbnb (2016). Introducing the Airbnb Policy Tool Chest. Available online at: https://news.airbnb.com/introducing-the-airbnb-policy-tool-chest/

Airbnb (2019). Beyond cities: How Airbnb Supports Rural Revitalization. Available online at: https://press.airbnb.com/wp-content/uploads/sites/4/2019/ 06/Beyond-Cities_Global-Report.pdf

Andersson, C., and Törnberg, P. (2018). Wickedness and the anatomy of complexity. Futures 95, 118-138. doi: 10.1016/j.futures.2017.11.001

Arendt, H. (1958). The Human Condition. Chicago, IL: University of Chicago Press.

Arendt, H. (1973). The Origins of Totalitarianism. Boston, MA: Houghton Mifflin Harcourt.

Arnouts, R., van der Zouwen, M., and Arts, B. (2012). Analysing governance modes and shifts-governance arrangements in Dutch through the "data traces" left on digital platforms (Törnberg, 2017). The same naïve naturalism seen in the depoliticization of self-organization as a political ideal is part of the social scientific conceptions of data as "raw" or "natural" unprocessed traces of social processes, central to Computational Social Science (Marres, 2017). While platforms have become power hubs pursuing their interests through sophisticated data manipulation, researchers are studying the data they provide without consideration of the political economy in which they were produced. Many scholars interested in digital social life have been lured by the siren-call of new methods and abundant digital data to lose their gaze from precisely the context and conditions underlying the production of these data (Törnberg and Törnberg, 2018).

This calls for a new critical study of social complexity; a critical computational science, in which "bottom-up" is not taken to mean spontaneous, natural or non-political, and in which conflicts and power-struggles are not erased, but brought to the fore. There is no such thing as raw data, and there is no such thing as truly bottom-up: structure and power always come into play in shaping the context and conditions for interaction. The role of such a critical complexity science would be the unveiling of the operation and mechanisms of complex control, making visible the implicit and hidden forms of power inherent in social technologies.

\section{AUTHOR CONTRIBUTIONS}

PT conceived the idea and wrote the first draft of the manuscript. JU discussed and revised the manuscript in several iterations. All authors contributed to the manuscript revision, read, and approved the submitted version.

\section{FUNDING}

This project has received funding from the European Union's Horizon 2020 research and innovation programme project ODYCCEUS (grant agreement no. 732942). The funders had no role in study design, data collection and analysis, decision to publish, or preparation of the manuscript. nature policy. For. Policy Econ. 16, 43-50. doi: 10.1016/j.forpol.2011. 04.001

Ashby, W. R. (1991). "Principles of the self-organizing system," in Facets of Systems Science, ed G. J. Klir (Berlin: Springer), 521-536. doi: 10.1007/978-1-4899-0718-9_38

Ball, P. (2012). Why Society is a Complex Matter: Meeting Twenty-First Century Challenges With a New Kind of Science. Berlin: Springer Science \& Business Media.

Barabási, A.-L., and Albert, R. (1999). Emergence of scaling in random networks. Science 286, 509-512. doi: 10.1126/science.286.54 39.509

Bar-Yam, Y. (1997). Dynamics of Complex Systems. Boca Raton, FL: CRC Press. Bauman, Z. (2013). Liquid Modernity. Hoboken, NJ: John Wiley \& Sons.

Benkler, Y. (2002). Coase's penguin, or, linux and "the nature of the firm." Yale Law J. 112, 369-446. doi: 10.2307/1562247 
Benkler, Y. (2006). The Wealth of Networks: How Social Production Transforms Markets and Freedom. New Haven, CT: Yale University Press.

Bentham, J. (1995). The Panopticon Writings. Brooklyn, NY: Verso Trade.

Blanco, I. (2015). Between democratic network governance and neoliberalism: a regime-theoretical analysis of collaboration in Barcelona. Cities 44, 123-130. doi: 10.1016/j.cities.2014.10.007

Bonabeau, E. (1998). Social insect colonies as complex adaptive systems. Ecosystems 1, 437-443. doi: 10.1007/s100219900038

Bottando, E. (2012). Hedging the commons: google books, libraries, and open access to knowledge (Ph.D. thesis), University of Iowa, Lowa, IA, United States.

Castellani, B., and Rajaram, R. (2016). Past the power law: complex systems and the limiting law of restricted diversity. Complexity 21, 99-112. doi: $10.1002 /$ cplx.21786

Chandler, D. (2014). Beyond neoliberalism: resilience, the new art of governing complexity. Resilience 2, 47-63. doi: 10.1080/21693293.2013.8 78544

Chiappini, L., and Törnberg, P. (2018). "Deus ex machina: makerspaces in milan and their transformative potential," in The Production of Alternative Urban Spaces, eds J. K. Fisker, L. Chiappini, L. Pugalis, and A. Bruzzese (Abingdon: Routledge), 73-92. doi: 10.4324/9781315103952-5

Conradson, D. (2016). "Freedom, space and perspective: moving encounters with other ecologies," in Emotional Geographies, eds J. Davidson, L. Bondi, and M. Smith (Abingdon: Routledge), 117-130.

Deleuze, G. (1992). Postscript on the societies of control. Winter 59, 3-7.

Elias, N. (1969). The Court Society. The English translation was actually published in 1983. Oxford: Basil Blackwell.

Ert, E., Fleischer, A., and Magen, N. (2016). Trust and reputation in the sharing economy: the role of personal photos in Airbnb. Tour. Manag. 55, 62-73. doi: 10.1016/j.tourman.2016.01.013

Feenberg, A. (2002). Transforming Technology: A Critical Theory Revisited. Oxford: Oxford University Press.

Feynman, R. (1964). The brownian movement. Feynman Lect. Phys. 1:41.

Folke, C. (2007). Social-ecological systems and adaptive governance of the commons. Eco. Res. 22, 14-15. doi: 10.1007/s11284-006-0074-0

Foucault, M. (1977). Discipline and Punish: The Birth of the Prison. New York, NY: Vintage.

Foucault, M. (2008). The Birth of Biopolitics: Lectures at the College de France, 1978-1979. Berlin: Springer.

Gane, N. (2012). The governmentalities of neoliberalism: panopticism, post-panopticism and beyond. Sociol. Rev. 60, 611-634. doi: 10.1111/j.1467-954X.2012.02126.X

Gershenson, C., Santi, P., and Ratti, C. (2016). Adaptive cities: a cybernetic perspective on urban systems. arXiv. Available online at: http://arxiv.org/abs/ 1609.02000 (accessed March 2, 2020).

Gomez-Uribe, C. A., and Hunt, N. (2016). The netflix recommender system: algorithms, business value, and innovation. ACM Trans. Manag. Inf. Syst. 6:13. doi: $10.1145 / 2843948$

Graham, S. D. N. (2005). Software-sorted geographies. Prog. Hum. Geogr. 29, 562-580. doi: 10.1191/0309132505ph568oa

Gunderson, L., and Light, S. S. (2006). Adaptive management and adaptive governance in the everglades ecosystem. Policy Sci. 39, 323-334. doi: $10.1007 /$ s1 1077-006-9027-2

Hallinan, B., and Striphas, T. (2016). Recommended for you: the netflix prize and the production of algorithmic culture. New Media Soc. 18, 117-137. doi: $10.1177 / 1461444814538646$

Halpern, O. (2015). Beautiful Data: A History of Vision and Reason Since 1945. Durham, NC: Duke University Press.

Harvey, D. (1989). From managerialism to entrepreneurialism: the transformation in urban governance in late capitalism. Geogr. Ann. B Hum. Geogr. 71, 3-17. doi: 10.1080/04353684.1989.11879583

Helbing, D. (ed.). (2015). "What the digital revolution means for us," in Thinking Ahead-Essays on Big Data, Digital Revolution, and Participatory Market Society(Berlin: Springer), 177-187. Available online at: https://www.springer. com/gp/book/9783319150772

Heylighen, F., Cilliers, P., and Gershenson, C. (2006). Complexity and philosophy. arXiv cs/0604072. Available online at: https://arxiv.org/ftp/cs/papers/0604/ 0604072.pdf (accessed November 2, 2017).

Horkheimer, M. (1972). Critical Theory: Selected Essays. London: A\&C Black.
Isin, E., and Ruppert, E. (2015). Being Digital Citizens. Lanham, MD: Rowman \& Littlefield International.

Jacobs, J. (1961). The Death and Life of Great American Cities. New York, NY: Random House.

Johnson, N. (2009). Simply Complexity: A Clear Guide to Complexity Theory. London: Oneworld Publications.

Jones, C., Hesterly, W. S., and Borgatti, S. P. (1997). A general theory of network governance: exchange conditions and social mechanisms. Acad. Manag. Rev. 22, 911-945. doi: 10.5465/amr.1997.9711022109

Joseph, J. (2013). Resilience as embedded neoliberalism: a governmentality approach. Resilience 1, 38-52. doi: 10.1080/21693293.2013.765741

Kingsbury, P., and Pile, S. (2016). Psychoanalytic Geographies. Abingdon: Routledge.

Kitchin, R., Lauriault, T. P., and Wilson, M. W. (2017). Understanding Spatial Media. Thousand Oaks, CA: Sage. doi: 10.4135/9781526425850

Krivý, M. (2018). Towards a critique of cybernetic urbanism: the smart city and the society of control. Plan. Theory 17, 8-30. doi: 10.1177/1473095216645631

Lane, D. A. (2016). Innovation cascades: artefacts, organization and attributions. Philos. Trans. R. Soc. Biol. Sci. 371:20150194. doi: 10.1098/rstb.2015.0194

Lanier, J. (2017). Dawn of the New Everything: A Journey Through Virtual Reality. New York, NY: Random House.

Liang, F., Das, V., Kostyuk, N., and Hussain, M. M. (2018). Constructing a datadriven society: China's social credit system as a state surveillance infrastructure. Policy Internet 10, 415-453. doi: 10.1002/poi3.183

Lupton, D. (2016). The Quantified Self. Hoboken, NJ: John Wiley \& Sons.

Marres, N. (2017). Digital Sociology: The Reinvention of Social Research. Hoboken, NJ: John Wiley \& Sons.

Mattijssen, T., Buijs, A., Elands, B., and Arts, B. (2018). The 'green' and 'self' in green self-governance-a study of 264 green space initiatives by citizens. J. Environ. Policy Plan. 20, 96-113. doi: 10.1080/1523908X.2017.1322945

Michod, R. E., and Nedelcu, A. M. (2003). On the reorganization of fitness during evolutionary transitions in individuality. Integr. Comp. Biol. 43, 64-73. doi: $10.1093 / \mathrm{icb} / 43.1 .64$

Mitchell, M. (2009). Complexity: A Guided Tour. Oxford: Oxford University Press.

Moisio, S., and Rossi, U. (2019). The start-up state: governing urbanised capitalism. Environ. Plan. A. doi: 10.1177/0308518X19879168

Plantin, J.-C., Lagoze, C., Edwards, P. N., and Sandvig, C. (2018). Infrastructure studies meet platform studies in the age of google and facebook. New Media Soc. 20, 293-310. doi: 10.1177/1461444816661553

Polanyi, K. (1944). The Great Transformation. Boston, MA: Beacon Press Boston.

Puschmann, T., and Alt, R. (2016). Sharing economy. Bus. Inf. Syst. Eng. 58, 93-99. doi: $10.1007 / \mathrm{s} 12599-015-0420-2$

Rijshouwer, E. (2019). Organizing democracy: power concentration and selforganization in the evolution of wikipedia (Ph.D. thesis), Erasmus University, Rotterdam, Netherlands.

Rossi, U. (2016). The variegated economics and the potential politics of the smart city. Terr. Polit. Govern. 4, 337-353. doi: 10.1080/21622671.2015.1036913

Rozin, P., and Royzman, E. B. (2001). Negativity bias, negativity dominance, and contagion. Personal. Soc. Psychol. Rev. 5, 296-320. doi: 10.1207/S15327957PSPR0504_2

Sassen, S. (2014). Expulsions. Cambridge, MA: Harvard University Press.

Sennett, R. (2012). The Stupefying Smart City. London: LSE Cities.

Sørensen, E., and Triantafillou, P. (2009). The politics of self-governance: an introduction. Polit. Self Govern. 1, 1-25. doi: 10.4324/9781315554259-1

Srnicek, N. (2017). Platform Capitalism. Hoboken, NJ: John Wiley \& Sons.

Stephens-Davidowitz, S., and Pinker, S. (2017). Everybody Lies: Big Data, New Data, and What the Internet Can Tell Us About Who We Really Are. New York, NY: HarperCollins New York.

Sundén, J. (2002). Material Virtualities: Approaching Online Textual Embodiment. Oxford: Peter Lang Inc.; International Academic Publishers.

Thaler, R. H., Sunstein, C. R., and Balz, J. P. (2013). "Choice architecture," in The Behavioral Foundations of Public Policy, ed E. Shafir (Princeton, NJ: Princeton University Press), 428-439.

Törnberg, P. (2017). Worse Than Complex, (PhD thesis), Chalmers University of Technology, Gothenburg, Sweden.

Törnberg, P., and Törnberg (2018). The limits of computation: a philosophical critique of contemporary big data research. Big Data Soc. doi: $10.1177 / 2053951718811843$ 
Uitermark, J. (2015). Longing for wikitopia: the study and politics of selforganisation. Urban Stud. 52, 2301-2312. doi: 10.1177/0042098015577334

Vaidhyanathan, S. (2012). The Googlization of Everything: (And Why We Should Worry). Berkeley, CA: University of California Press.

van Dijck, J. and Poell, T. (2013). Understanding social media logic. Media Commun. 1, 2-14. doi: 10.12924/mac2013.01010002

van Doorn, N. (2019). A new institution on the block: on platform urbanism and airbnb citizenship. New Media Soc. doi: 10.1177/1461444819884377

Vanolo, A. (2019). "Playable urban citizenship: Social justice and the gamification of civic life," in The Right to the Smart City, eds P. Cardullo, C. Di Feliciantonio, and R. Kitchin (Bingley: Emerald Publishing Limited), 57-69. doi: 10.1108/978-1-78769-139-120191004

Wacquant, L. (2010). Crafting the neoliberal state: workfare, prisonfare, and social insecurity. Sociol. Forum 25, 197-220. doi: 10.1111/j.1573-7861.2010.01173.x

Weinmann, M., Schneider, C., and vom Brocke, J. (2016). Digital nudging. Bus. Inf. Syst. Eng. 58, 433-436. doi: 10.1007/s12599-016-0453-1

Whitehurst, J. (2016). The real power of platforms is helping people self-organize. Harvard Business Review. Available on at: https://hbr.org/2016/04/the-realpower-of-platforms-is-helping-people-self- organize (accessed March 2, 2020).

Wiener, N. (1948). Cybernetics or Control and Communication in the Animal and the Machine. Cambridge, MA: Technology Press.
Zandbergen, D., and Uitermark, J. (2019). In search of the smart citizen: republican and cybernetic citizenship in the smart city. Urban Stud. doi: $10.1177 / 0042098019847410$

Zuckerberg, M. (2019). Facebook and Free Speech. Available online at: https://www. youtube.com/watch?v=hcLSU17M3Lw

Zumbrun, J., and Talley, I. (2018). World Bank unfairly influenced its own competitiveness rankings. The Wall Street Journal. Available on at: https://www. wsj.com/articles/world-bank-unfairly-influenced-its-own-competitivenessrankings- 1515797620 (accessed March 2, 2020).

Conflict of Interest: The authors declare that the research was conducted in the absence of any commercial or financial relationships that could be construed as a potential conflict of interest.

Copyright $\odot 2020$ Törnberg and Uitermark. This is an open-access article distributed under the terms of the Creative Commons Attribution License (CC BY). The use, distribution or reproduction in other forums is permitted, provided the original author(s) and the copyright owner(s) are credited and that the original publication in this journal is cited, in accordance with accepted academic practice. No use, distribution or reproduction is permitted which does not comply with these terms. 